\title{
Effect of vitamin D supplementation on HbA1c level in a cohort of type 1 diabetic patients
}

\begin{abstract}
Background and objective: Glycemic control is essential to halt the progression of diabetic complications. Some studies previously showed the effect of vitamin $D$ on pancreatic $\beta$-cell function and insulin secretion. This study aimed to assess the effect of vitamin $D$ supplementation on $\mathrm{HbA1c}$ in patients with type 1 diabetes and vitamin $D$ deficiency.

Methods: This prospective quasi-experimental study was conducted in Erbil city from $1^{\text {st }}$ September to $1^{\text {st }}$ December 2019. In this study, 76 patients attending Layla Qasim diabetic center were tested. Only 50 patients were recruited that had vitamin D deficiency (25OHD: $<20$ ) and were aged less than 18 years. They received vitamin D supplementation for 12 weeks. HbA1c and vitamin D level was measured before and after supplementation.

Results: Before vitamin D supplementation, the mean level of serum $25(\mathrm{OH}) \mathrm{D}$ among females $(8.67 \pm 2.56)$ was lower than males $(14.31 \pm 3.19)$. However, no association was found between the initial $\mathrm{HbA} 1 \mathrm{c}$ level and gender. HbA1c level (mean = $8.24 \pm 0.49$ ) improved significantly after vitamin $D$ supplementation to the level of $7.93 \pm 0.67$ $(P=0.032)$. There was a significant difference between groups of glycosylated hemoglobin levels of (first tertile $<7.5 \%$, second tertile $7.6 \%-9.9 \%$, third tertile $\geq 10 \%$ ) after 12 weeks of supplementation with vitamin $\mathrm{D}(P<0.001)$.

Conclusion: Vitamin D supplementation in type 1 diabetic patients with vitamin $D$ deficiency lead to significant improvement in HbA1c level.
\end{abstract}

Keywords: Diabetes; Deficiency; Vitamin D.

\section{Introduction}

Diabetes mellitus is a chronic progressive disease that is characterized by an elevated level of glucose in the blood. Type 1 diabetes results from insufficient insulin production, which usually happens in children and was previously known as insulin-dependent or childhood-onset DM. ${ }^{1}$ The exact cause of type 1 diabetes mellitus is unknown, although there are a number of theories that relate type 1 diabetes mellitus to genetic or environmental factors such as perinatal infections, cesarean section, low maternal intake of vegetables, early exposure to cereals, eggs, cow's milk and many others which eventually lead to the destruction of B cells in the pancreas which is responsible for insulin production. ${ }^{2,3}$
The incidence of type 1 diabetes mellitus in European countries has been increasing yearly, reaching several folds in the last three decades. ${ }^{3}$ It is supposed that in 2020 the number of new cases of type 1 diabetes mellitus will be doubled in children under five years old, and the prevalence will increase by 1.7 times in children under 15 years old age. ${ }^{4} \mathrm{HbA} 1 \mathrm{c}$ is a good indicator of metabolic control in diabetic patients, and it is less affected by food intake and daily activity as it is in other tests in addition to its predictive value for microvascular complication. ${ }^{5,6}$

Vitamin $D$ is a fat-soluble vitamin usually obtained from exposure to sunlight. Also, it is found in very few foods or is given as a dietary supplement. The consumption of

${ }^{1}$ Rapareen Pediatric Hospital, Erbil, I raq.

${ }^{2}$ Department of Pediatrics, College of Medicine, Hawler Medical University, Erbil, I raq.

* Correspondence: myagoran@yahoo.com 
vitamin $D$ through these methods is inert and needs activation, which is done in two stages of hydroxylation. ${ }^{7}$ In the last decade, it has been found that vitamin $D$ has an effect not only on musculoskeletal function (calcium homeostasis and bone metabolism) but beyond that, as vitamin $D$ receptor has been found in most of the tissues and organs of the body such as skin, placenta, pancreas, colon, cancer cells and many other areas of the body. However, very little is known about these receptors. $^{8}$

Vitamin $D$ receptors are also available in pancreatic $\beta$-cells. ${ }^{9}$ It has been reported that mutated vitamin $D$ receptors have been associated with impaired insulin secretion. ${ }^{10}$

A study on animal models found impaired vitamin $D$ signaling system had been shown to be the result of abnormal vitamin $D$ receptors leading to glucose intolerance and impairment in the gene encoding insulin in these mice. ${ }^{11}$ Vitamin $D$ receptors polymorphisms have been associated with type 1 diabetes. ${ }^{12-15}$

There are many studies showing the effect of vitamin $D$ on type 1 diabetes mellitus. ${ }^{16-18}$ According to the researcher's knowledge, there is no such study done in the Kurdistan region.

This study aimed to determine the effect of vitamin D supplementation on $\mathrm{HbA} 1 \mathrm{c}$ level in patients with type 1 diabetes and vitamin $D$ deficiency.

\section{Methods}

A prospective quasi-experimental study was conducted to show the effect of vitamin D supplementation on $\mathrm{HbA} 1 \mathrm{c}$ level in type 1 diabetic patients with vitamin $D$ deficiency before and after vitamin D supplementation. The study was conducted in Layla Qasim diabetic center in Erbil city, the capital city of Kurdistan region of Iraq, from 1st September of 2019 till 1st December of 2019.

A systematic sampling method was used to select patients from a total of 984 registered type 1 patients aged less than
18 years old at Layla Qasim diabetic center. Every 10th patient was selected from the list of registered type 1 patients. Out of 98 patients interviewed, only 76 were tested for the initial vitamin $D$ level. The 22 patients not involved in the study either refused or were excluded. The exclusion criteria included chronic renal disease, celiac disease, patients already on vitamin D supplementation, on medications that interfere with vitamin $D$ metabolism, hypothyroidism, any acute illness such as acute febrile illness, recent documented infection or inflammation and recent admission to hospital for diabetic ketoacidosis. Out of 76 patients, only 50 patients were vitamin $\mathrm{D}$ deficient (25OHD: $<20)^{19}$ and were recruited. No other data was collected about those patients with sufficient vitamin $D$.

Recruited patients were assigned to receive vitamin $D$ according to the safe upper limit dose recommended by the American Diabetic Association (1,000$1,500 \mathrm{IU} /$ day for infants, $2,500-3,000$ IU/day for children aged 1-8 years, and 4,000 IU/day for children $\geq 9$ years of age, adults). ${ }^{20}$ Vitamin $D$ was provided in the form of syrup or tablet of the same manufacturer according to age and acceptance of the patient.

No further therapeutic interventions were performed, and the family was instructed that the child should continue the same dose of insulin and lifestyle till the end of the study.

Then after 12 weeks from starting the supplementation, vitamin $D$ level and glycosylated hemoglobin ( $\mathrm{HbA1c})$ were measured again. They were compared with the initial readings to evaluate the effect of vitamin $\mathrm{D}$ supplementation on $\mathrm{HbA} 1 \mathrm{c}$ level. Both serum 25-hydroxy vitamin $D$ and HbA1c level were measured using Cobas 6000 (Roche Diagnostics, Hitachi, Tokyo, Japan).

$\mathrm{HbA1c}$ levels were divided into three categories: first tertile $(\mathrm{HbA} 1 \mathrm{c}<7.5 \%)$, second tertile (HbA1c:7.6\%-9.9\%), and third tertile $(\mathrm{HbA} 1 \mathrm{c} \geq 10 \%) .{ }^{21,22}$ 
The body mass index (BMI) was calculated by dividing weight $(\mathrm{kg})$ over squared height (m2). The BMI-z score was graded according to CDC growth charts. ${ }^{23}$

The research proposal was accepted by the ethical committee of the Kurdistan Board of Medical Specialties. Informed consent taken from the caregiver of patients before participating in the study. The anonymity of patients was preserved.

Data analysis was performed by using the statistical package for the social sciences (SPSS version 24). Student's t-test was used to compare the means of two groups (gender, residency regarding $\mathrm{HbA} 1 \mathrm{c}$ level, and serum $25(\mathrm{OH}) \mathrm{D})$.

One-way analysis of variance (one-way ANOVA) test was used to compare means of more than two groups (age groups, duration categories, BMI, insulin regimens, insulin dose, regarding $\mathrm{HbA} 1 \mathrm{c}$ level and serum 25(OH)D).

McNemar test was used to compare the percentage of patients' glycemic control group before and after vitamin D supplementation. Paired T-test was done to compare the mean $\mathrm{HbA} 1 \mathrm{c}$ level before and after vitamin $\mathrm{D}$ supplementation.

Simple linear regression was used to evaluate the association between the grade of post-HbA1c level change and change in the serum $25(\mathrm{OH}) \mathrm{D}$ level with the vitamin $D$ supplementation. A $P$ value of $<0.05$ was defined as statistically significant.

\section{Results}

This study recruited 50 type 1 diabetic patients with vitamin $D$ deficiency; 19 males $(38 \%)$ and 31 females $(62 \%)$. The patients' age range was $2-17$ years $(52 \%$ aged $2-10$ years, $32 \%$ aged $11-14$ years, and $16 \%$ aged $15-17$ years) with a mean of $10.14 \pm 3.93$ years. Forty-eight patients $(96 \%)$ were from urban residence, while only two patients (4\%) were from rural residence.

At the stage of recruitment, the mean duration of diabetes was $3.77 \pm 3.19$ years, as shown in Table 1.

Table 1 Association between patients' variables with initial serum 25(OH)D

\begin{tabular}{|c|c|c|c|c|}
\hline Variables & Mean \pm SD $^{*}$ & No (\%) & 25(OH)D (Mean \pm SD) & $P$ value \\
\hline Age (years) & $10.14 \pm 3.93$ & & & 0.541 \\
\hline $2-10$ & & $26(52 \%)$ & $10.26 \pm 3.47$ & \\
\hline $11-14$ & & $16(32 \%)$ & $10.00 \pm 3.47$ & \\
\hline $15-17$ & & $8(16 \%)$ & $11.02 \pm 4.05$ & \\
\hline Gender & & & & $<0.001$ \\
\hline Male & & $19(38 \%)$ & $14.31 \pm 3.19$ & \\
\hline Female & & $31(62 \%)$ & $8.67 \pm 2.56$ & \\
\hline Residency & & & & 0.663 \\
\hline Urban & & $48(96 \%)$ & $10.77 \pm 3.86$ & \\
\hline Rural & & $2(4 \%)$ & $12.00 \pm 7.07$ & \\
\hline $\mathrm{BMI}^{+}\left(\mathrm{kg} / \mathrm{m}^{2}\right)$ & $18.25 \pm 2.87$ & & & 0.189 \\
\hline Normal & & $43(86 \%)$ & $11.11 \pm 3.95$ & \\
\hline Overweight & & $7(14 \%)$ & $9.00 \pm 3.41$ & \\
\hline Duration (years) & $3.77 \pm 3.19$ & & & 0.405 \\
\hline$<4$ & & $30(60 \%)$ & $9.96 \pm 3.70$ & \\
\hline $4-8$ & & $15(30 \%)$ & $10.26 \pm 3.26$ & \\
\hline 9-12 & & $5(10 \%)$ & $10.54 \pm 5.27$ & \\
\hline Insulin regiment & & & & 0.192 \\
\hline Multiple injections & & $43(86 \%)$ & $37.56 \pm 11.67$ & \\
\hline Premixed two dose injection & & $6(12 \%)$ & $36.67 \pm 19.15$ & \\
\hline Insulin pump & & $1(2 \%)$ & 65 & \\
\hline
\end{tabular}


Association between patients' variables with initial $\mathrm{HbA} 1 \mathrm{c}$ and serum $25(\mathrm{OH}) \mathrm{D}$ is shown in Table 1 and Table 2.

The initial mean level of serum $25(\mathrm{OH}) \mathrm{D}$ among females $(8.67 \pm 2.56 \mathrm{ng} / \mathrm{mL})$ was lower than males $(14.31 \pm 3.19 \mathrm{ng} / \mathrm{mL}$ ). A statistically significant association was found between gender and initial serum 25(OH)D level $(P<0.001)$. However, no association was found between the initial $\mathrm{HbA} 1 \mathrm{c}$ level and gender $(P=0.245)$.

No significant difference was found among age groups regarding initial serum $25(\mathrm{OH})$ $\mathrm{D}(P=0.541)$ and initial $\mathrm{HbA1c}(P=0.342)$. Body mass index was not associated with the initial serum 25(OH)D level $(P=0.189)$ and initial $\operatorname{HbA1c}(P=0.545)$ value, respectively. There was no statistically significant association between initial serum 25(OH)D level and the initial $\mathrm{HbA1c}$ with the residency of the patients $(P=0.663$ and 0.107 , respectively).

About insulin regimens, $86 \%$ of patients were on multiple injections (mean $37.56 \pm 11.67$ ), followed by $12 \%$ of patients on premixed two dose insulin injections (mean 36.67 \pm 19.15 ). The insulin pump was used only by $2 \%$ (mean of 65 units), as is shown in Table 1. No statistically significant difference was found among insulin regimens regarding initial $\mathrm{HbA} 1 \mathrm{c}$ $(P=0.178)$ and initial serum $25(\mathrm{OH}) \mathrm{D}$ $(P=0.192)$, as it is shown in Table 2 and 1 , respectively.

Table 2 Association between patients' variables with initial $\mathrm{HbA} 1 \mathrm{c}$

\begin{tabular}{|c|c|c|}
\hline Variables & HbA1c (Mean \pm SD) & $P$ value \\
\hline Age (years) & & 0.342 \\
\hline $2-10$ & $8.15 \pm 0.38$ & \\
\hline $11-14$ & $8.37 \pm 0.58$ & \\
\hline $15-17$ & $8.28 \pm 0.55$ & \\
\hline Gender & & 0.245 \\
\hline Male & $8.34 \pm 0.45$ & \\
\hline Female & $8.18 \pm 0.51$ & \\
\hline Residency & & 0.107 \\
\hline Urban & $8.22 \pm 0.34$ & \\
\hline Rural & $8.80 \pm 0.30$ & \\
\hline $\mathrm{BMI}^{+}(\mathrm{kg} / \mathrm{m} 2)$ & & 0.545 \\
\hline Normal & $8.29 \pm 0.49$ & \\
\hline Overweight & $7.91 \pm 0.27$ & \\
\hline Duration (years) & & 0.528 \\
\hline$<4$ & $8.22 \pm 0.50$ & \\
\hline $4-8$ & $8.34 \pm 0.45$ & \\
\hline $9-12$ & $8.06 \pm 0.48$ & \\
\hline Insulin regiment & & 0.178 \\
\hline Multiple injections & $37.56 \pm 11.67$ & \\
\hline Premixed two dose injection & $36.67 \pm 19.15$ & \\
\hline Insulin pump & 65 & \\
\hline
\end{tabular}

${ }^{*}$ Standard deviation, ${ }^{+}$Body mass index 
The mean dose of vitamin $D$ By doing linear regression, it has been supplementation was $3860 \pm 995 \mathrm{IU} /$ day. The difference in the mean $\mathrm{HbA} 1 \mathrm{c}$ level before $(8.24 \pm 0.49)$ and after $(7.93 \pm 0.67)$ vitamin $D$ supplementation was statistically significant $(P=0.032)$. Also, the percentage of patients' glycemic control groups was statistically significant after vitamin D supplementation $(P<0.001)$, as shown in Table 3. found that the change in the serum $25(\mathrm{OH})$ $\mathrm{D}$ level with the vitamin $\mathrm{D}$ supplementation was significantly associated with the grade of the response of post $\mathrm{HbA} 1 \mathrm{c}$ level (the more increase in the serum $25(\mathrm{OH}) \mathrm{D}$ level, the lower post $\mathrm{HbA1c}$ level) (B $=-0.29, P=0.003)$, as shown in Table 4.

Table 3 Glycemic control before and after vitamin D supplementation

\begin{tabular}{lccccc}
\hline $\begin{array}{l}\text { Glycemic control } \\
\text { groups }\end{array}$ & \multicolumn{2}{c}{ Before supplementation } & \multicolumn{2}{c}{ After supplementation } & $P$ value \\
& Count & $(\%)$ & Count & $(\%)$ & \\
\hline First tertile & 8 & $(16.0)$ & 12 & $(24.0)$ & $<0.001$ \\
Second tertile & 11 & $(22.0)$ & 37 & $(74.0)$ & \\
Third tertile & 31 & $(62.0)$ & 1 & $(2.0)$ & \\
$\begin{array}{l}\text { Pre- HbA1c } \\
\text { (Mean } \pm \text { SD) }\end{array}$ & $8.24 \pm 0.49$ & $\begin{array}{l}\text { Post- HbA1c } \\
(\text { Mean } \pm \text { SD) }\end{array}$ & $7.93 \pm 0.67$ & 0.032 \\
\hline
\end{tabular}

* Glycosylated hemoglobin.

Table 4 Regression analysis of the change in the serum 25(OH)D level predicting post HbA1c level

HbA1c level after vitamin D supplementation

$\begin{array}{llllll}\text { B } & 95 \% \mathrm{Cl} & \text { SE B } & \beta & \text { T } & P \text { value }\end{array}$

\begin{tabular}{lcccccc}
\hline (Constant) & 8.941 & $8.33-9.545$ & 0.300 & 29.814 & 0 \\
Vit D3 difference & -0.29 & $-0.47-(-0.010)$ & 0.009 & -0.410 & -3.112 & 0.003
\end{tabular}

B: Unstandardized beta, $\mathrm{Cl}$ : Confidence interval for unstandardized beta, SE B: Standard error for the unstandardized beta, $\beta$ : Standardized beta, $t$ : $t$-test statistic, $R^{2}=0.168$, Adjusted $R^{2}=-0.151$ 


\section{Discussion}

Diabetes mellitus can lead to the development of several complications. Studies have shown the importance of good glycemic control in reducing the risk of micro and macro vascular complication in type 1 and type 2 diabetes mellitus. ${ }^{24}$ Risk for the development of diabetic complications, morbidity, and mortality can be minimized by decreasing HbA1c level. ${ }^{25}$

Serum 25(OH)D before vitamin D administration were lower among females $(8.67 \pm 2.56) \mathrm{ng} / \mathrm{mL}$ than males (14.31 \pm 3.19) $\mathrm{ng} / \mathrm{mL}(P<0.001)$ (table 1$)$. A similar figure was also reported by Al-Agha. ${ }^{16}$ However, Mutlu found no difference in Serum 25(OH)D between males and females. ${ }^{26}$ This could be attributed to the difference in the cultural influences and traditions. $^{27}$

Besides gender, none of other demographic (age, residence) and clinical factors (BMI and duration of disease) were found to have an effect on and initial serum 25(OH)D and initial HbA1c. Many studies did not find an association between demographic and clinical factors mentioned above with Serum 25(OH)D and HbA1c among patients less than 18 years old. ${ }^{18,25,28}$

Our results showed that mean pre intervention HbA1c level improved significantly from $(8.24 \pm 0.49)$ to $(7.93 \pm$ 0.67) after supplementation $(P=0.032)$ (Table3). A similar result was reported by Mohammadian that $\mathrm{HbA1c}$ level improved (from $9.73 \pm 1.85$ to $8.55 \pm 1.91$ ) after vitamin D supplementation $(P<0.0001) .{ }^{29}$ A similar figure was also found by Aljabri. ${ }^{25}$ In addition to this result, our study showed improvement in patients number and percent in all glycemic groups (first tertile $<7.5 \%$, second tertile $7.6 \%-9.9 \%$, third tertile $\geq 10 \%$ ) after vitamin D supplementation (Table 3). In contrast, a study by El Baba showed no significant relationship between glycemic control and variation of vitamin $\mathrm{D}$ level. ${ }^{30}$

Vitamin $D$ deficiency may contribute to the development of insulin resistance and the impairment of the secretion of insulin. ${ }^{31}$ Vitamin $D$ reduces the excessive release of insulin (in reaction to increased blood sugar) by decreasing insulin resistance. Thus, it improves insulin sensitivity. Vitamin $D$ deficiency is also correlated with $\beta$-cell dysfunction. Vitamin $D$ enhances the conversion of pro-insulin as well as $\beta$-cells capacity for insulin production. ${ }^{32}$

In our study, improvement of glycemic control was observed only after 12 weeks; we do not know if the improvement of glycemic control after vitamin supplementation would carry on further. This study had a number of limitations. The design did not include a control group (no placebo control). It is not known if the patients or their caregivers did any change of insulin dose without informing us during or after the vitamin D supplementation. Finally, the study had a small number of patients recruited.

\section{Conclusion}

Supplementing vitamin D to type 1 diabetic patients with vitamin $D$ deficiency leads to improvement in glycosylated hemoglobin level. Also, we concluded that vitamin D level is affected by the gender of the patient. However, neither the patients' age, BMI, nor the duration of diabetes affects vitamin D level or HbA1c level.

\section{Funding}

None.

\section{Competing interests}

None declared.

\section{References}

1. Kahanovitz L, Sluss PM, Russell SJ. Type 1 Diabetes - A Clinical Perspective. Point Care. 2017; 16(1):37-40. https://doi.org/10.1097/ POC.0000000000000125.

2. Katsarou A, Gudbjörnsdottir S, Rawshani A, Dabelea D, Bonifacio E, Anderson BJ, et al. Type 1 diabetes mellitus. Nat Rev Dis Primers. 2017; 3(1):1-7. https://doi.org/10.1038/nrdp.2017.16.

3. Rewers M, Ludvigsson J. Environmental risk factors for type 1 diabetes. Lancet. 2016; 387 (10035):2340-8. https://doi.org/10.1016/S0140 -6736(16)30507-4. 
4. Patterson CC, Gyürüs E, Rosenbauer J, Cinek O, Neu A, Schober E, et al. Trends in childhood type 1 diabetes incidence in Europe during 1989-2008: evidence of non-uniformity over time in rates of increase. Diabetologia. 2012; 55(8):2142-7. https://doi.org/10.1007/s00125012-2571-8.

5. Harvard Medical School. Type 1 Diabetes Mellitus: What is it, Boston, USA: Harvard Medical School; 2018. https://www.health.harvard.edu/ a to z/type-1-diabetes-mellitus-a-to-z. Accessed 2 Apr 2020.

6. Florkowski C. HbA1c as a Diagnostic Test for Diabetes Mellitus - Reviewing the Evidence. Clin Biochem Rev. 2013; 34(2):75-83.

7. National Institutes of Health. Vitamin D: Fact Sheet for Health Professionals USA: NIH. https://ods.od.nih.gov/factsheets/VitaminDHealthProfessional. Accessed 8 Apr 2020.

8. Christakos S, Hewison M, Gardner DG, Wagner CL, Sergeev IN, Rutten E, et al. Vitamin D: beyond bone. Ann N Y Acad Sci. 2013; 1287 (1):45-58. https://doi.org/10.1111/nyas.12129.

9. Hummel D, Aggarwal A, Borka K, Bajna E, Kállay $E$, Horváth $H C$. The vitamin $D$ system is deregulated in pancreatic diseases. J Steroid Biochem Mol Biol. 2014; 144(Pt B):402-9. https://doi.org/10.1016/j.jsbmb.2014.07.011.

10. Sung CC, Liao MT, Lu KC, Wu CC. Role of vitamin $D$ in insulin resistance. J Biomed Biotechnol. 2012; 2012:634195. https://doi.org/10.1155/2012/634195.

11. Benetti E, Mastrocola R, Chiazza F, Nigro D, D'Antona $G$, Bordano $V$, et al. Effects of vitamin $D$ on insulin resistance and myosteatosis in diet-induced obese mice. PLoS One. 2018; 13(1):e0189707. https://doi.org/10.1371/journal.pone.0189707.

12. Ali R, Fawzy I, Mohsen I, Settin A. Evaluation of vitamin $D$ receptor gene polymorphisms (Fok-I and Bsm-I) in T1DM Saudi children. J Clin Lab Anal. 2018; 32(5):e22397. https://doi.org/10.1002/jcla.22397.

13. Yang CY, Leung PS, Adamopoulos IE, Gershwin ME. The implication of vitamin $D$ and autoimmunity: a comprehensive review. Clin Rev Allergy Immunol. 2013; 45(2):217-26. https://doi.org/10.1007/s12016-013-8361-3.

14. Abd-Allah SH, Pasha HF, Hagrass HA, Alghobashy AA. Vitamin D status and vitamin D receptor gene polymorphisms and susceptibility to type 1 diabetes in Egyptian children. Gene 2014; 536(2):430-4. https:// doi.org/10.1016/j.gene.2013.12.032.

15. Sahin OA, Goksen D, Ozpinar A, Serdar M, Onay H. Association of vitamin D receptor polymorphisms and type 1 diabetes susceptibility in children: a metaanalysis. Endocr Connect. 2017; 6(3):159-71. https://doi.org/10.1530/EC-16-0110.
16. Al-Agha AE, Ahmad IA. Association among vitamin $D$ deficiency, type 1 diabetes mellitus and glycemic control. J Diabetes Metab. 2015; 6(594). https://doi.org/10.4172/21556156.1000594.

17. Savastio S, Cadario F, Genoni G, Bellomo G, Bagnati M, Secco G, et al. Vitamin D deficiency and glycemic status in children and adolescents with type 1 diabetes mellitus. PloS One. 2016; 11(9):e0162554. https://doi.org/10.1371/journal.pone.0162554.

18. Elsayed AM, Mohamed GA. Vitamin D deficiency and its correlation to hemoglobin $\mathrm{A} 1 \mathrm{C}$ in adolescent and young adult type 1 diabetes mellitus patients. AAMJ. 2016; 14(2):76-80. https://doi.org/10.4103/1687-1693.192643.

19. Shin YH, Shin HJ, Lee YJ. Vitamin D status and childhood health. Korean J Pediatr. 2013;56 (10):417-23. https://doi.org/10.3345/ kjp.2013.56.10.417.

20. Martin T, Campbell RK. Vitamin D and diabetes. Diabetes Spectr. 2011; 24(2):113-8.

21. Kliegman RM. Nelson Textbook of Pediatrics. $20^{\text {th }}$ ed. Philadelphia: Elsevier; 2016. P. 2777.

22. American Diabetes A. 2. Classification and Diagnosis of Diabetes: Standards of Medical Care in Diabetes-2018. Diabetes Care 2018; 41(Suppl 1):S13-27. https://doi.org/10.2337/ dc16-er09.

23. Centers for Disease Control and Prevention, National Center for Health Statistics. CDC growth charts: United States. http://www.cdc.gov/growthcharts/. Accessed 30 May 2020.

24. Bergenstal RM. Glycemic variability and diabetes complications: does it matter? Simply put, there are better glycemic markers! Diabetes Care. 2015; 38:1615-21. https://doi.org/10.2337/dc15-0099.

25. Aljabri KS, Bokhari SA, Khan MJ. Glycemic changes after vitamin $D$ supplementation in patients with type 1 diabetes mellitus and vitamin D deficiency. Ann Saudi Med. 2010; 30(6):454-8. https://doi.org/10.4103/02564947.72265.

26. Mutlu A, Mutlu GY, Özsu E, Çizmecioğlu FM, Hatun Ş. Vitamin D deficiency in children and adolescents with type 1 diabetes. J Clin Res Pediatr Endocrinol. 2011; 3(4):179-83. https://doi.org/10.4274/jcrpe.430.

27. Omar M, Nouh F, Younis M, Younis M, Nabil N, Saad $M$, et al. Culture, Sun Exposure and Vitamin D Deficiency in Benghazi Libya. J Adv Med Med Res. 2018; 25(5):1-13. https://doi.org/10.9734/JAMMR/2018/39562.

28. Nansel TR, Lipsky LM, lannotti RJ. Crosssectional and longitudinal relationships of body mass index with glycemic control in children and adolescents with type 1 diabetes mellitus. Diabetes Res Clin. 2013; 100(1):126-32. https://doi.org/10.1016/j.diabres.2012.12.025. 
Effect of vitamin D supplementation on HbAlc ...

Zanco J. Med. Sci., Vol. 25, No. (3), December, 2021

https:/ / doi.org/ 10.15218/ zjms.2021.031

29. Mohammadian S, Fatahi N, Zaeri H, Vakili MA. Effect of vitamin D3 supplement in glycemic control of pediatrics with type 1 diabetes mellitus and vitamin d deficiency. JCDR. 2015; 9(3):SC05-7. https://doi.org/10.7860/ JCDR/2015/10053.5683.

30. El Baba K, Zantout MS, Akel R, Azar ST. Seasonal variation of vitamin $D$ and $\mathrm{HbA}(1 \mathrm{c})$ levels in patients with type 1 diabetes mellitus in the Middle East. Int J Gen Med. 2011; 4:635 -8. https://doi.org/10.2147/IJGM.S23548.

31. Kavadar G, Demircioğlu DT, Özgönenel L, Emre TY. The relationship between vitamin D status, physical activity and insulin resistance in overweight and obese subjects. Bosn J Basic Med Sci. 2015; 15(2):62-6. https://doi.org/10.17305/bjbms.2015.399.

32. Karnchanasorn R, Ou HY, Chiu KC. Plasma 25-hydroxyvitamin $D$ levels are favorably associated with $\beta$-cell function. Pancreas. 2012; 41(6):863-8. https://doi.org/10.1097/ MPA.0b013e31823c947c. 